A.K. Shuaibov, A.I. Minya, R.V. Grytsak, A.A. Malinina, I.V. Shevera, M.I. Vatrala, Z.T. Gomoki

\title{
Investigation of the Conditions of Synthesis of Metal and Chalcopyrite Films from the Degradation Products of Electrodes of an Overstressed Nanosecond Discharge in Argon and Air
}

\author{
Uzhgorod National University, Uzhgorod,Ukarine, alexsander.shuaibov@uzhnu.edu.ua
}

\begin{abstract}
The characteristics of an overstressed bipolar discharge with a duration of $100-150 \mathrm{~ns}$ in argon and air, which was ignited between copper electrodes in argon, and also between an aluminum electrode and a chalcopyrite $\left(\mathrm{CuInSe}_{2}\right)$ electrode in air, are presented. In the process of microexplosions of inhomogeneities on the working surfaces of the electrodes in a strong electric field, vapor of copper, aluminum and vapor of ternary chalcopyrite are introduced into the interelectrode gap. This creates the prerequisites for the synthesis of thin copper films and the synthesis of films based on quaternary chalcopyrite - $\mathrm{CuAlInSe}$, which can be deposited on a quartz plate installed near the center of the discharge gap.

The optical characteristics of the plasma, as well as voltage pulses across the discharge gap of $\mathrm{d}=1-2 \mathrm{~mm}$, current pulses and pulsed energy contributions to the discharge, have been investigated using emission spectroscopy with a high time resolution. The plasma emission spectra were thoroughly studied, which made it possible to establish the main decay products of the chalcopyrite molecule and the energy states of atoms and singly charged ions of aluminum, copper and indium, which are formed in the discharge.

On the basis of the destruction products of aluminum and ternary chalcopyrite electrodes, thin films, which may have the composition of quaternary chalcopyrite, have been deposited outside the plasma, and the transmission spectra of thin films deposited at different air pressures in the discharge chamber are studied.

Key words: discharge, chalcopyrite films, argon, electrodes.
\end{abstract}

Received 2 November 2020; Accepted 15 December 2020.

\section{Introduction}

The development of nanosecond and subnanosecond high-current electronics has led to wide applications of these devices in various fields of physics and technology [1]. The study of powerful nanosecond discharges between metal electrodes in air showed that they can be used to develop selective "point" UV lamps on metal vapors, and it is also possible to synthesize film nanostructures of copper, zinc and iron oxides under conditions of intense irradiation of the substrate and the film with bactericidal UV radiation [2-5]. The search for new applications for similar discharges with a strong overvoltage of the interelectrode gaps is also of practical interest [6].

With a nanosecond discharge in air in short discharge gaps $(\mathrm{d}=0.5-3 \mathrm{~mm})$, the formation of ectons is observed, which is accompanied by microexplosions of natural inhomogeneities on the surface of metal or semiconductor electrodes and the release of vapors of the electrode material into the gaseous medium [7]. In a discharge in inert gases between electrodes made of transition metals $(\mathrm{Cu}, \mathrm{Zn}, \mathrm{Fe})$, it is possible to synthesize nanostructured metal films, and in a discharge between aluminum electrodes and an electrode from ternary chalcopyrite $\mathrm{CuInSe}_{2}$, it is possible to synthesize thin films of quaternary chalcopyrite of the $\mathrm{CuIn}_{1-\mathrm{x}} \mathrm{Al}_{\mathrm{x}} \mathrm{Se}_{2}$ type. In [8], it was reported on the manufacture of a thinfilm solar cell $\mathrm{CuIn}_{1-\mathrm{x}} \mathrm{Al}_{\mathrm{x}} \mathrm{Se}_{2}$ (CIASe), where the optimal aluminum content relative to the sum of the indium and aluminum concentrations $\mathrm{Al} /\left(\begin{array}{ll}\mathrm{In} & \mathrm{Al}\end{array}\right)$ was $\approx 0.2$. Comparison of these values with similar values for solar 
cells made without aluminum showed a significant improvement in the efficiency of a device based on $\mathrm{CuIn}_{1-\mathrm{x}} \mathrm{Al}_{\mathrm{x}} \mathrm{Se}_{2}$ due to an increase in the energy gap of the absorber in quaternary alloys. Therefore, the search for new plasma methods for the synthesis of thin films based on complex semiconductor compounds such as quaternary chalcopyrite continues to remain important for micro-nanoelectronics.

Nanostructures of pure metals or complex chalcopyrites are currently obtained by various physical methods from the gas phase with thermal, laser [9] and magnetron sputtering. Laser methods for the synthesis of nanostructures are valuable and require the use of qualified personnel, while other gas-discharge methods require the use of cost-effective high-vacuum equipment.

There are practically no data on the study of the conditions for the synthesis of film nanostructures or fine powders based on transition metals $(\mathrm{Cu}, \mathrm{Zn}$, and $\mathrm{Fe})$ in an overstressed nanosecond discharge; therefore, the problem of studying the synthesis conditions and the main characteristics of such nanostructures in inert and molecular gases is urgent, which is impossible without the use of valuable laser or vacuum equipment.

The process of synthesis of nanostructures obtained using discharge overvoltages in gases between copper and chalcopyrite electrodes is always accompanied by intense irradiation of the substrate with nanosecond discharge plasma in the spectral range of $200-300 \mathrm{~nm}$ $[10,11]$, which is important for improving their electrical characteristics. For example, it was indicated in [12] that assisting the growth of transparent conducting layers based on zinc oxide nanostructures by UV radiation from a mercury lamp improves their electrical characteristics by creating additional donor centers and reducing the scattering of charge carriers at the grain boundaries of nanowhiskers. For the synthesis of thin nanostructured films from the products of sputtering copper-containing electrodes in an overstressed nanosecond discharge, there is no need to use an external source of UV radiation, since the studied plasma itself is an emitter in the spectral range $\lambda=200-230 \mathrm{~nm}$.

Finely dispersed copper powders are currently used in lubricating compositions, which allows them to be used in various friction units [13]. Copper powders of various sizes are used as fillers from polyethylene, which contributes to a monotonic increase in stress, its destruction and modulus of elasticity in bending [14], and they also find application in microbiology and medicine in the manufacture of broad-spectrum medical materials [15]. Ultrafine copper powders have high catalytic activity in redox reactions, which is important for their applications in chemistry. They are also used (as an effective bactericidal material) in air filtration systems, where they are characterized by high sensitivity to pathogenic microorganisms for a long time [16]. Therefore, it is important to further develop new methods for the synthesis of thin nanostructured copper films and for the preparation of finely dispersed copper particles.

The article presents the results of a study of the characteristics of an overstressed nanosecond discharge between copper electrodes in argon, as well as between an aluminum electrode and a triple chalcopyrite electrode in air; based on the products of electrode sputtering, thin films based on vapors of aluminum and ternary chalcopyrite $\left(\mathrm{CuInSe}_{2}\right)$ have been synthesized, the results of the study of light transmission spectra from the spectral range of $200-500 \mathrm{~nm}$ by thin films synthesized in the experiment, which were deposited on quartz substrates outside the discharge from the products of material erosion $\left(\mathrm{Al}+\mathrm{CuInSe}_{2}\right)$, are presented

\section{Experimental technique and conditions}

A high-current nanosecond discharge between copper electrodes, as well as between an aluminum electrode and an electrode from chalcopyrite $\left(\mathrm{CuInSe}_{2}\right)$, was ignited in a sealed Plexiglas chamber. The diagram of the discharge module and the device for the deposition of thin films is shown in Fig. 1. It is described in more detail in [4, 17]. The distance between the copper electrodes was $\mathrm{d}=2 \mathrm{~mm}$, and between the aluminum electrode and the chalcopyrite electrode - $1 \mathrm{~mm}$. This made it possible to achieve a significant overvoltage of the discharge gap at pressures of argon or air $\mathrm{p}=6.7$; $13.3 \mathrm{kPa}$, respectively. The discharge chamber was evacuated by a foreline pump to a residual pressure of $10 \mathrm{~Pa}$, and then argon or air was let in into the chamber to a pressure of 6.7 or $13.3 \mathrm{kPa}$. The diameter of the cylindrical electrodes was $5 \mathrm{~mm}$, and the radius of curvature of their working end surface was the same and equal to $-3 \mathrm{~mm}$.

The discharge was ignited using a bipolar highvoltage modulator of voltage pulses with a total duration of voltage pulses of 50-150 ns with an amplitude of positive and negative components of $\pm 20-40 \mathrm{kV}$. The voltage pulse repetition frequency was chosen equal to $100 \mathrm{~Hz}$, since at high frequencies the discharge module was significantly heated. Oscillograms of voltage pulses across the discharge gap and oscillograms of current pulses were recorded using a broadband capacitive voltage divider, a Rogowski coil, and a 6LOR-04 broadband oscilloscope with a time resolution of 2 - 3 ns.

An MDR-2 monochromator and a photomultiplier (FEU-106) were used to record the plasma emission spectra. The signal from the photomultiplier was fed to an amplifier and was recorded using an amplitude-digital converter in an automated system for measuring spectra on a personal computer display. The discharge radiation was investigated in the spectral range of $200-650 \mathrm{~nm}$.

The results of control experiments to study the characteristics of this discharge at different air pressures in systems, when two identical electrodes made of aluminum or chalcopyrite were used, are given in $[18$, 19]. The interelectrode distance in both cases was $1 \mathrm{~mm}$, which made it possible to compare the results of these studies with the data of experiments with a discharge between different electrodes (electrode with "Al" and "CuInSe ${ }_{2}$ ").

In all cases, at gas pressures of 6.7 or $13.3 \mathrm{kPa}$, the discharge was spatially uniform, which is due to the reionization of the gaseous medium from the beam of electrons escaping from the plasma and the accompanying X-ray radiation [20]. The discharge volume depended on the voltage pulse repetition rate. 


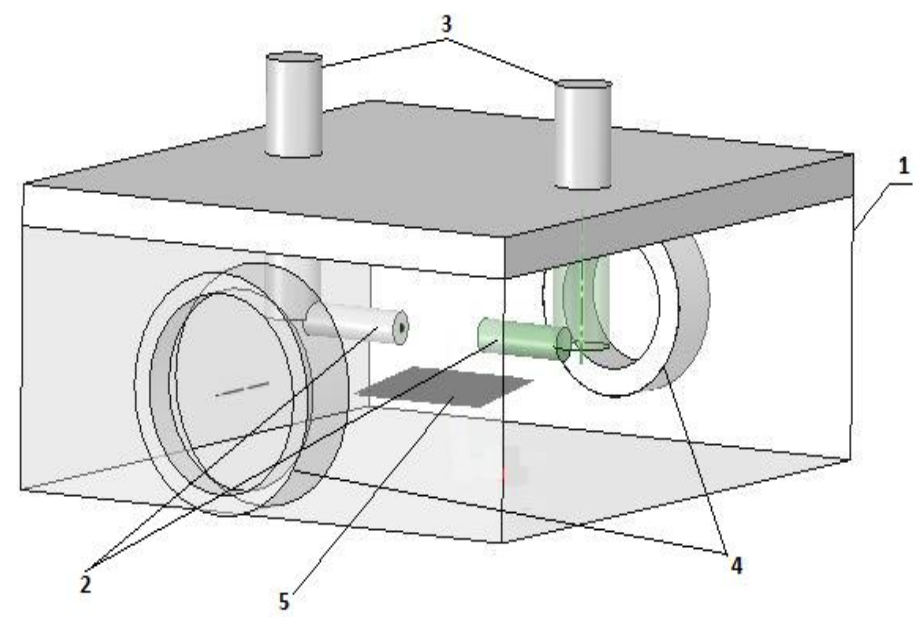

Fig. 1. The structure of the module with a system of electrodes for an overstressed nanosecond discharge in gases: 1 - the body of the discharge chamber, 2 - electrodes ("Cu", "Al", "CuInSe ${ }_{2}$ "), 3 - high-voltage inputs, 4 - quartz windows for monitoring the discharge and recording spectra, 5 - substrate for the deposition of thin films.

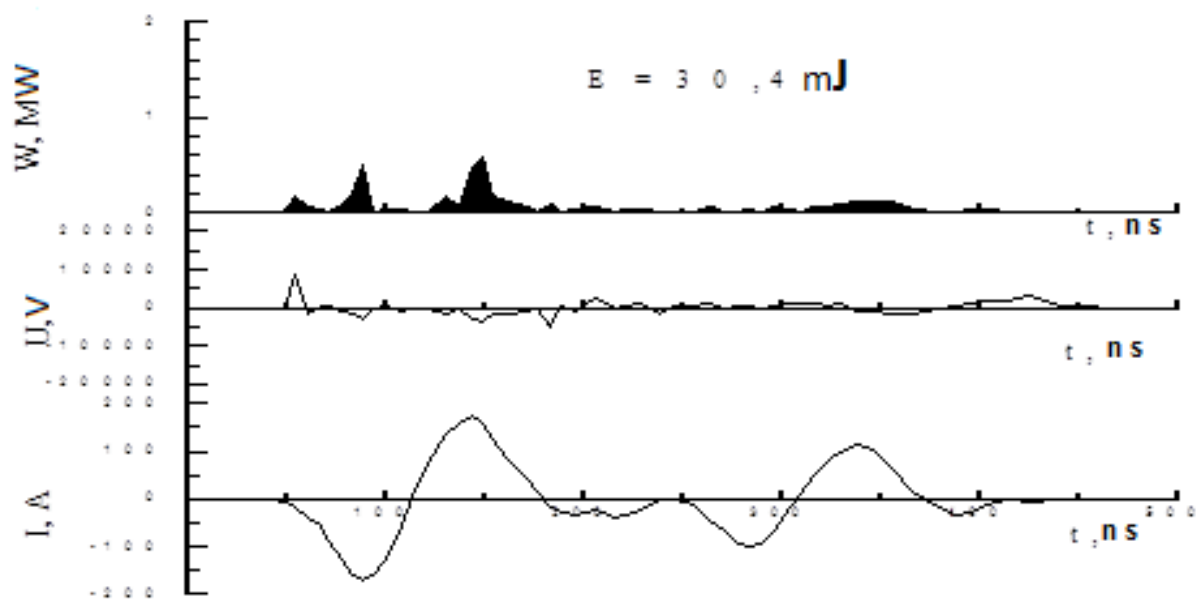

Fig. 2. Temporal dependences of the pulsed electric power of the discharge, the voltage between the copper electrodes and the current of a nanosecond discharge at an interelectrode distance $\mathrm{d}=2 \mathrm{~mm}$ in argon

$$
(\mathrm{p}(\mathrm{Ar})=6.7 \mathrm{kPa}) \text {. }
$$

The "point discharge" mode was achieved only at voltage pulse repetition rates in the range $\mathrm{f}=40-150 \mathrm{~Hz}$. With a short-term increase in frequency to $1000 \mathrm{~Hz}$, the plasma volume of the gas-discharge emitter grew up to $100 \mathrm{~mm}^{3}$.

Figure 2, 3 shows oscillograms of voltage, current and pulsed power for overvoltages of a nanosecond discharge between copper electrodes $(\mathrm{p}(\mathrm{Ar})=6.7 \mathrm{kPa})$, as well as an aluminum electrode and a triple chalcopyrite electrode $(\mathrm{p}($ air $)=13.3 \mathrm{kPa})$.

Oscillograms of voltage and current were in the form of oscillations decaying in time with a duration of about 7 - $10 \mathrm{~ns}$, which is due to a mismatch between the output resistance of the high-voltage modulator and the load resistance. The total duration of oscillations of the voltage across the gap and of the discharge current reached $450 \mathrm{~ns}$, with the duration of individual oscillations of voltage $7-10 \mathrm{~ns}$, current about $70 \mathrm{~ns}$.
Short-term oscillations showed up better in voltage waveforms. On the oscillograms of the current, they were smoothed (integrated over time) due to the large time constant of the Rogowski coil, which was used in these studies.

For a discharge in argon, the amplitude of the largest voltage drop at the electrodes was achieved at the initial stage of the discharge and was $\approx+8 \mathrm{kV}$, current $\pm 160 \mathrm{~A}$, and the pulse power - 0.6 MW, which ensured an energy contribution per discharge pulse to the plasma at a level of 30, $4 \mathrm{~mJ}$ (Fig. 2).

The maximum voltage drop across the discharge gap in air $(\mathrm{p}=13.3 \mathrm{kPa})$ was $8-10 \mathrm{kV}$, taking into account the positive to negative voltage amplitude. The maximum current amplitude reached 250 - $300 \mathrm{~A}$, and the pulsed power and the energy contribution to the plasma were 1.8 MW and $165 \mathrm{~mJ}$, respectively (Fig. 3). 


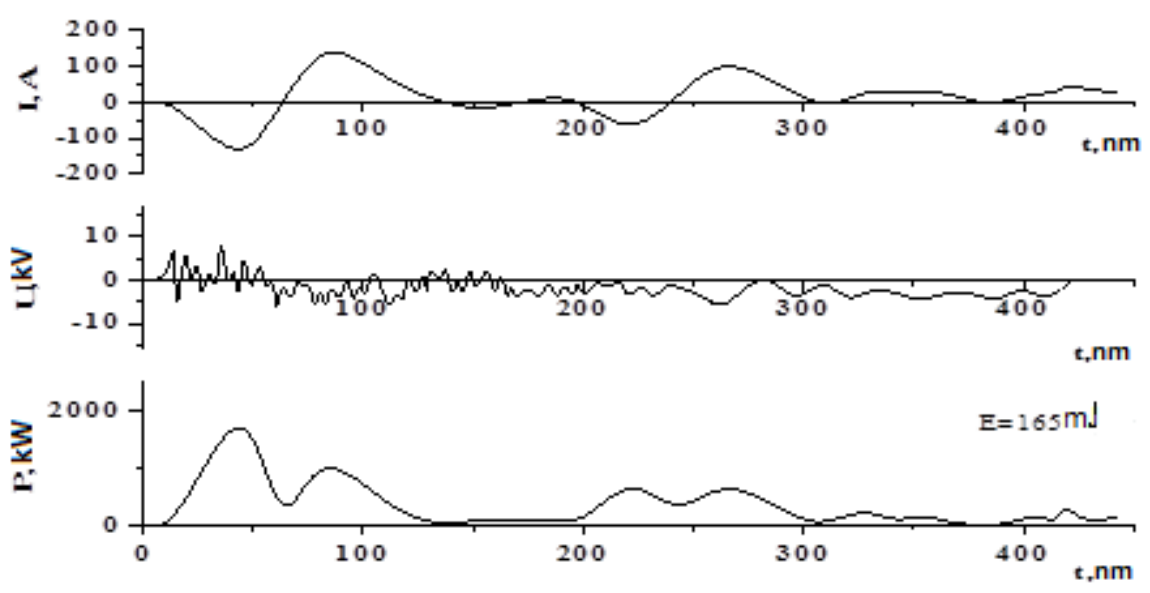

Fig. 3. Oscillograms of current, voltage and pulsed power of an overstressed bipolar nanosecond discharge between electrodes made of aluminum and chalcopyrite $\left(\mathrm{CuInSe}_{2}\right)$ at an air pressure of $13.3 \mathrm{kPa}(\mathrm{d}=1 \mathrm{~mm})$.

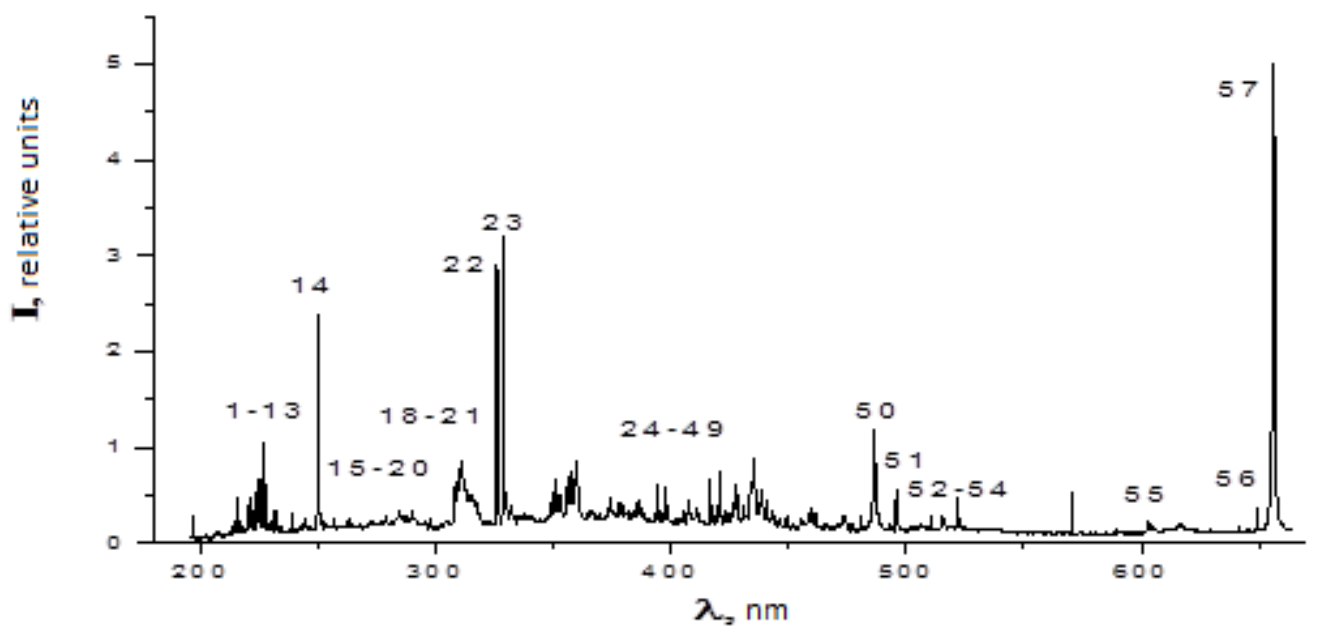

Fig. 4. Radiation spectrum of an overstressed nanosecond discharge between copper electrodes in argon $(\mathrm{p}(\mathrm{Ar})=6.7 \mathrm{kPa})$.

\section{Optical characteristics}

Control studies of the spectral characteristics of plasma radiation were carried out for an overstressed nanosecond discharge in air between two aluminum electrodes and between two electrodes from chalcopyrite $\left(\mathrm{CuInSe}_{2}\right)[18,19]$. When identifying spectral lines in the spectra, reference books [21-23] were used.

In the emission spectrum of the discharge on a mixture of argon with copper vapor in the UV range of wavelengths 214 - 306 nm (Fig. 4; lines 1-17; Table 1), emission was observed at atomic transitions and a singly charged copper ion. The most intense ionic spectral line was the $\lambda=224.70 \mathrm{~nm} \mathrm{Cu} 11$ line, and of the atomic, the most intense was the line with $\lambda=226.20 \mathrm{~nm} \mathrm{Cu} 1$. Thehighest energy of the upper level for the $\mathrm{Cu} 11$ lines was $\mathrm{E}_{\mathrm{up}}=14.70 \mathrm{eV}$, and for atomic lines the maximum energy of the upper level was $\mathrm{E}_{\text {up. }}=7.18 \mathrm{eV}$. Intense in the UV part of the spectrum were resonance spectral lines with $\lambda=324.75$ and $327.39 \mathrm{~nm}$ of $\mathrm{Cu} \mathrm{I}$, in which the lower energy level is the main level. In the UV spectrum, bands of the second positive system were also observed.

In the UV spectrum, bands of the second positive system of the nitrogen molecule were also observed, since in the experiments we used argon of "technical" purity, and the discharge chamber was evacuated to a residual pressure of $10 \mathrm{~Pa}$. In the wavelength range of $360-659 \mathrm{~nm}$, radiation was observed mainly at the transitions Ar 1, Ar11, as well as an intense spectral line of the hydrogen atom $(\lambda=656.29 \mathrm{H} \alpha)$, which is caused by air impurities in argon and the residual air pressure in the chamber after it pumping out with a the foreline pump.

To elucidate the nature of continuous plasma radiation of a discharge in a vapor-gas mixture "air - $\mathrm{Al}$ $\mathrm{CuInSe}_{2} "$ in the spectral range of $200-550 \mathrm{~nm}$, which already began to manifest itself at a pressure of air or mixtures of nitrogen with oxygen equal to $5-10 \mathrm{kPa}$ and significantly increased in intensity at atmospheric pressures of oxygen-containing gases [19], the emission spectrum of the discharge plasma between two aluminum electrodes in a nitrogen-oxygen mixture was investigated (Fig. 5). 
Investigation of the Conditions of Synthesis of Metal and Chalcopyrite Films...

Table 1

Results of identification of the radiation spectrum of the plasma of an overstressed nanosecond discharge between copper electrodes $(\mathrm{p}(\mathrm{Ar})=6.7 \mathrm{kPa} ; \mathrm{d}=2 \mathrm{~mm})$

\begin{tabular}{|c|c|c|c|c|c|c|c|}
\hline № & $\lambda_{\text {table }}, \mathrm{nm}$ & I, a.u. & Object & $\mathrm{E}_{\text {low... }} \mathrm{eV}$ & $\mathrm{E}_{\text {up., }} \mathrm{eV}$ & Lower term & Upper term \\
\hline 1 & 214.89 & 0.23 & $\mathrm{Cu}$ II & 1.39 & 7.18 & $4 \mathrm{~s}^{2}{ }^{2} \mathrm{D}$ & $5 f^{2} F^{\circ}$ \\
\hline 2 & 216.50 & 0.48 & $\mathrm{Cu} \mathrm{I}$ & 0.00 & 5.72 & $4 \mathrm{~s}^{2} \mathrm{~S}$ & $4 p^{\prime 2} D^{0}$ \\
\hline 3 & 217.49 & 0.19 & $\mathrm{Cu}$ II & 8.92 & 14.61 & $4 p^{1} F^{0}$ & $4 d^{1} G$ \\
\hline 4 & 220.05 & 0.38 & $\mathrm{Cu}$ II & 9.06 & 14.70 & $4 p^{3} D^{0}$ & $4 d^{3} F$ \\
\hline 5 & 221.45 & 0.47 & $\mathrm{Cu} \mathrm{I}$ & 1.39 & 6.98 & $4 \mathrm{~s}^{2}{ }^{2} \mathrm{D}$ & $4 p^{\prime \prime}{ }^{2} \mathrm{P}^{0}$ \\
\hline 6 & 223.84 & 0.68 & $\mathrm{Cu} \mathrm{I}$ & 1.64 & 7.18 & $4 \mathrm{~s}^{22} \mathrm{D}$ & $5 \mathrm{f}^{2} \mathrm{~F}^{\mathrm{o}}$ \\
\hline 7 & 224.70 & 0.67 & $\mathrm{Cu}$ II & 2.72 & 8.23 & $4 \mathrm{~s}^{3} \mathrm{D}$ & $4 p^{3} \mathrm{P}^{\circ}$ \\
\hline 8 & 226.30 & 1.06 & $\mathrm{Cu} \mathrm{I}$ & 1.64 & 7.12 & $4 \mathrm{~s}^{22} \mathrm{D}$ & $7 p^{2} \mathrm{P}^{\circ}$ \\
\hline 9 & 229.43 & 0.23 & $\mathrm{Cu}$ II & 2.83 & 8.23 & $4 \mathrm{~s}^{3} \mathrm{D}$ & $4 p^{3} \mathrm{P}^{0}$ \\
\hline 10 & 230.31 & 0.35 & $\mathrm{Cu} \mathrm{I}$ & 1.64 & 7.02 & $4 \mathrm{~s}^{22} \mathrm{D}$ & $4 p^{\prime \prime 2} D^{0}$ \\
\hline 11 & 236.98 & 0.17 & $\mathrm{Cu}$ II & 3.26 & 8.49 & $4 s^{1} D$ & $4 p^{3} \mathrm{~F}^{0}$ \\
\hline 12 & 239.26 & 0.30 & $\mathrm{Cu} \mathrm{I}$ & 1.64 & 6.82 & $4 \mathrm{~s}^{22} \mathrm{D}$ & $6 p^{2} \mathrm{P}^{\circ}$ \\
\hline 13 & 244.16 & 0.26 & $\mathrm{Cu} \mathrm{I}$ & 0.00 & 5.08 & $4 s^{2} S$ & $4 p^{\prime 4} \mathrm{P}^{0}$ \\
\hline 14 & 249.21 & 2.41 & $\mathrm{Cu} \mathrm{I}$ & 0.00 & 4.97 & $4 s^{2} S$ & $4 p^{\prime 4} \mathrm{P}^{\circ}$ \\
\hline 15 & 261.83 & 0.24 & $\mathrm{Cu} \mathrm{I}$ & 1.39 & 6.12 & $4 \mathrm{~s}^{2}{ }^{2} \mathrm{D}$ & $5 p^{2} \mathrm{P}^{\mathrm{o}}$ \\
\hline 16 & 282.43 & 0.34 & $\mathrm{Cu} \mathrm{I}$ & 1.39 & 5.78 & $4 \mathrm{~s}^{2}{ }^{2} \mathrm{D}$ & $4 p^{\prime 2} D^{0}$ \\
\hline 17 & 306.34 & 0.65 & $\mathrm{Cu} \mathrm{I}$ & 1.64 & 5.68 & $4 s^{22} \mathrm{D}$ & $4 p^{\prime 2} \mathrm{P}^{\circ}$ \\
\hline 18 & 310.40 & 0.87 & $\mathrm{~N}_{2}$ & \multicolumn{4}{|c|}{ Second positive system $\mathrm{C}^{3} \Pi_{\mathrm{u}^{+}}-\mathrm{B}^{3} \Pi_{\mathrm{g}}{ }^{+}(4 ; 3)$} \\
\hline 19 & 311.67 & 0.50 & $\mathrm{~N}_{2}$ & \multicolumn{4}{|c|}{ Second positive system $\mathrm{C}^{3} \Pi_{\mathrm{u}^{+}}-\mathrm{B}^{3} \Pi_{\mathrm{g}}{ }^{+}(3 ; 2)$} \\
\hline 20 & 313.60 & 0.54 & $\mathrm{~N}_{2}$ & \multicolumn{4}{|c|}{ Second positive system $\mathrm{C}^{3} \Pi_{\mathrm{u}}{ }^{+}-\mathrm{B}^{3} \Pi_{\mathrm{g}}{ }^{+}(2 ; 1)$} \\
\hline 21 & 315.93 & 0.51 & $\mathrm{~N}_{2}$ & \multicolumn{4}{|c|}{ Second positive system $\mathrm{C}^{3} \Pi_{\mathrm{u}}{ }^{+}-\mathrm{B}^{3} \Pi_{\mathrm{g}}{ }^{+}(1 ; 0)$} \\
\hline 22 & 324.75 & 1.42 & $\mathrm{Cu} \mathrm{I}$ & 0 & 3.82 & $4 \mathrm{~s}^{2} \mathrm{~S}$ & $4 p^{2} \mathrm{P}^{0}$ \\
\hline 23 & 327.39 & 1.43 & $\mathrm{Cu} \mathrm{I}$ & 0 & 3.39 & $4 \mathrm{~s}^{2} \mathrm{~S}$ & $4 p^{2} \mathrm{P}^{0}$ \\
\hline 24 & 354.89 & 0.57 & $\mathrm{~N}_{2}$ & \multicolumn{4}{|c|}{ Second positive system $\mathrm{C}^{3} \Pi_{\mathrm{u}^{+}}-\mathrm{B}^{3} \Pi_{\mathrm{g}}{ }^{+}(3 ; 2)$} \\
\hline 25 & 357.69 & 0.76 & $\mathrm{~N}_{2}$ & \multicolumn{4}{|c|}{ Second positive system $\mathrm{C}^{3} \Pi_{\mathrm{u}^{+}-\mathrm{B}^{3} \Pi_{\mathrm{g}}{ }^{+}(0 ; 1)}$} \\
\hline 26 & 360.65 & 0.85 & Ar I & 11.62 & 15.06 & $4 \mathrm{~s}\left[\begin{array}{lll}1 & 1 / 2\end{array}\right]^{\circ}$ & $6 \mathrm{p}[1 / 2]$ \\
\hline 27 & 373.78 & 0.48 & Ar II & 21.50 & 24.81 & $4 p^{\prime 2} D^{o}$ & $4 \mathrm{~d}^{\prime 2} \mathrm{~F}$ \\
\hline 28 & 377.05 & 0.41 & Ar II & 19.30 & 22.59 & $4 p^{4} \mathrm{P}^{0}$ & $5 s^{4} \mathrm{P}$ \\
\hline 29 & 378.63 & 0.42 & Ar II & 16.41 & 19.68 & $3 d^{4} \mathrm{D}$ & $4 p^{2} D^{\circ}$ \\
\hline 30 & 385.05 & 0.43 & Ar II & 16.75 & 19.97 & $4 s^{4} \mathrm{P}$ & $4{ }^{4} S_{0}$ \\
\hline 31 & 386.85 & 0.45 & Ar II & 19.97 & 23.17 & $4 p^{4} S_{0}$ & $4 d^{4} \mathrm{P}$ \\
\hline 32 & 387.52 & 0.35 & Ar II & 16.44 & 19.64 & $3 d^{4} D$ & $4 p^{4} D^{0}$ \\
\hline 33 & 394.30 & 0.61 & $\mathrm{~N}_{2}$ & \multicolumn{4}{|c|}{ Second positive system $C^{3} \Pi_{u}{ }^{+}-B^{3} \Pi_{g}{ }^{+}(2 ; 5)$} \\
\hline 34 & 397.93 & 0.58 & Ar II & 19.97 & 23.08 & $4 p{ }^{4} S_{0}$ & $4 d^{4} P$ \\
\hline 35 & 402.26 & 0.28 & $\mathrm{Cu} \mathrm{I}$ & 3.79 & 6.87 & $4 \mathrm{p}^{2} \mathrm{P}^{0}$ & $5 d^{2} D$ \\
\hline 36 & 405.29 & 0.34 & Ar II & 20.74 & 23.80 & $4 \mathrm{~s}^{\prime \prime 2} \mathrm{~S}$ & $4 p^{\prime \prime 2} P^{0}$ \\
\hline 37 & 407.95 & 0.44 & Ar II & 18.45 & 21.49 & $4 \mathrm{~s}^{\prime 2} \mathrm{D}$ & $4 p^{\prime 2} D^{0}$ \\
\hline 38 & 411.28 & 0.37 & Ar II & 16.75 & 19.76 & $4 s^{4} \mathrm{P}$ & $4 p^{2} D^{0}$ \\
\hline 39 & 415.85 & 0.66 & Ar I & 11.55 & 14.53 & $4 \mathrm{~s}[1 / 2]^{0}$ & $5 p\left[\begin{array}{ll}1 & 1 / 2\end{array}\right]$ \\
\hline 40 & 420.06 & 0.75 & ArI & 11.55 & 14.50 & $4 \mathrm{~s}[1 / 2]^{0}$ & $5 p\left[\begin{array}{ll}2 & 1 / 2\end{array}\right]$ \\
\hline 41 & 425.93 & 0.41 & Ar I & 11.83 & 14.74 & $4 s^{\prime}[1 / 2]^{0}$ & $5 p^{\prime}[1 / 2]$ \\
\hline 42 & 427.81 & 0.62 & $\mathrm{~N}_{2}$ & \multicolumn{4}{|c|}{ Second positive system $\mathrm{C}^{3} \Pi_{\mathrm{u}^{+}-\mathrm{B}^{3} \Pi_{\mathrm{g}}{ }^{+}(0 ; 1)}$} \\
\hline 43 & 433.35 & 0.81 & Ar I & 11.83 & 14.69 & $4 s^{\prime}[1 / 2]^{0}$ & $5 p^{\prime}[11 / 2]$ \\
\hline 44 & 435.50 & 0.90 & $\mathrm{~N}_{2}$ & \multicolumn{4}{|c|}{ Second positive system $\mathrm{C}^{3} \Pi_{\mathrm{u}}{ }^{+}-\mathrm{B}^{3} \Pi_{\mathrm{g}}{ }^{+}(4 ; 9)$} \\
\hline 45 & 441.67 & 0.44 & $\mathrm{~N}_{2}$ & \multicolumn{4}{|c|}{ Second positive system $\mathrm{C}^{3} \Pi_{\mathrm{u}}{ }^{+}-\mathrm{B}^{3} \Pi_{\mathrm{g}}{ }^{+}(3 ; 8)$} \\
\hline 46 & 442.39 & 0.33 & Ar I & 11.72 & 14.52 & $4 s^{\prime}[1 / 2]^{\circ}$ & $5 p^{\prime}[11 / 2]$ \\
\hline 47 & 459.60 & 0.38 & Ar I & 11.83 & 14.52 & $4 s^{\prime}[1 / 2]^{0}$ & $5 p^{\prime}[11 / 2]$ \\
\hline 48 & 460.95 & 0.33 & $\mathrm{Ar}$ II & 18.45 & 21.14 & $4 s^{\prime 2} \mathrm{D}$ & $4 \mathrm{p}^{\prime 2} \mathrm{~F}^{\mathrm{o}}$ \\
\hline 49 & 470.23 & 0.20 & $\mathrm{Ar} \mathrm{I}$ & 11.83 & 14.46 & $4 s^{\prime}[1 / 2]^{0}$ & $5 p^{\prime}\left[11 \frac{1}{2}\right]$ \\
\hline 50 & 487.62 & 1.21 & Ar I & 12.91 & 15.45 & $4 p[1 / 2]$ & $7 \mathrm{~d}\left[1 \frac{1}{2}\right]$ \\
\hline 51 & 495.67 & 0.57 & Ar I & 13.08 & 15.58 & $4 p\left[2^{1 / 2}\right]$ & $9 \mathrm{~d}[3 \mathrm{k} / 2]$ \\
\hline 52 & 511.82 & 0.28 & Ar I & 13.09 & 15.52 & $4 \mathrm{p}\left[2^{1 / 2}\right]$ & $6 \mathrm{~d}^{\prime}\left[2 \frac{1}{2}\right]^{0}$ \\
\hline 53 & 516.22 & 0.27 & Ar I & 12.91 & 15.31 & $4 p[1 / 2]$ & $6 \mathrm{~d}[1 / 2]$ \\
\hline
\end{tabular}


Table 1

(continuation)

\begin{tabular}{|c|l|c|c|c|c|c|c|}
\hline 54 & 521.82 & 0.46 & $\mathrm{Cu} \mathrm{I}$ & 3.82 & 6.19 & $4 \mathrm{p}^{2} \mathrm{P}^{\mathrm{o}}$ & $4 \mathrm{~d}^{2} \mathrm{D}$ \\
\hline 55 & 570.02 & 0.52 & $\mathrm{Cu} \mathrm{I}$ & 1.64 & 3.82 & $4 \mathrm{~s}^{2} \mathrm{D}$ & $4 \mathrm{p}^{2} \mathrm{P}^{\mathrm{o}}$ \\
\hline 56 & 653.81 & 0.37 & $\mathrm{Ar} \mathrm{I}$ & 13.08 & 14.95 & $4 \mathrm{p}\left[2 \frac{1}{2}\right]$ & $4 \mathrm{~d}^{\prime}[1 / 2]^{\mathrm{o}}$ \\
\hline \multirow{2}{*}{57} & $\begin{array}{l}656,29+ \\
659.61\end{array}$ & 5 & $\mathrm{H} \mathrm{H}_{\alpha}$ & & & & \\
& & $\mathrm{Ar} \mathrm{I}$ & 13.08 & 14.95 & $4 \mathrm{p}\left[2 \frac{1}{2}\right]$ & $4 \mathrm{~d}^{\prime}[1 / 2]^{\circ}$ \\
\hline
\end{tabular}

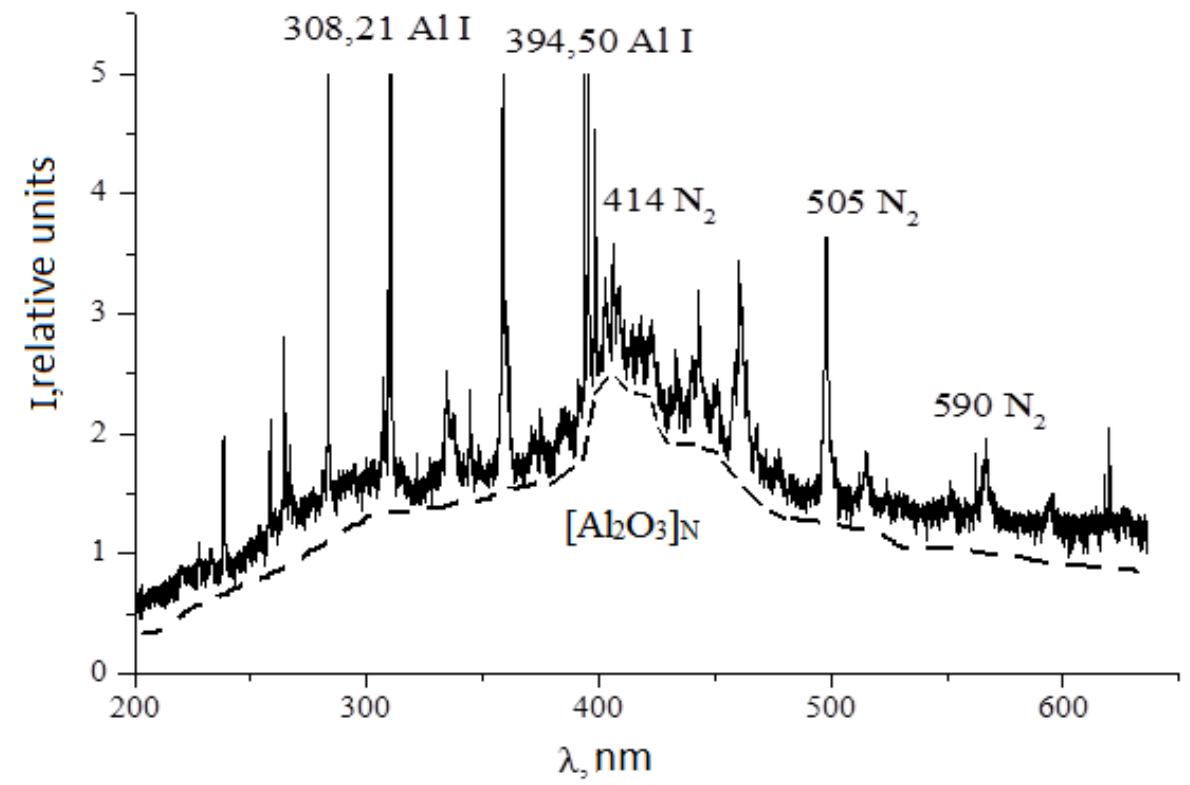

Fig. 5. Radiation spectrum of overvoltage of a nanosecond discharge between aluminum electrodes in a mixture of nitrogen and oxygen $(100-1 ; \mathrm{p}=101.3 \mathrm{kPa})$, dashed line $-\left[\mathrm{Al}_{2} \mathrm{O}_{3}\right] \mathrm{N}$ - designation of aluminum oxide nanoparticles.

In the emission spectra of a discharge based on oxygen-containing gases (air or a mixture of nitrogen and oxygen) with impurities of aluminum vapor [19], broad emission bands were recorded with maxima in the spectral ranges of $410-420 \mathrm{~nm}$ and $300-390 \mathrm{~nm}$ (Fig. 4). The highest radiation intensity of these bands is obtained at pressures of oxygen-containing gases of 100 $200 \mathrm{kPa}$. In a discharge in argon-based mixtures, these bands were observed in the emission spectra of overstressed nanosecond discharge plasma. In [24], the results of studying the cathodoluminescence spectra of nanostructured ceramics of aluminum oxide are presented. The spectrum of this cathodoluminescence was almost identical to the spectrum that was obtained in our study of overvoltage radiation of a nanosecond discharge at air pressures of $10-202 \mathrm{kPa}$ or in a mixture of nitrogen with oxygen ( $p=101 \mathrm{kPa}$; Fig. 4.). In these spectra, the main one was the emission band with a maximum at $=410-420 \mathrm{~nm}$ (quantum energy $3.0 \mathrm{eV}$ ), to which a broader short-wavelength band with maxima of the quantum energy at $\mathrm{E}=3.4 ; 3.8 ; 4.3 \mathrm{eV}$ was adjacted. The ultraviolet photo- and cathodoluminescence bands of nanostructured aluminum oxide are associated with the radiation of $\mathrm{F}^{+}$-centers formed by oxygen vacancies [25]. Therefore, with a high degree of probability, the nature of continuous radiation in the investigated discharge with aluminum electrodes in oxygen-containing gases is due to the radiation of nanostructures of aluminum oxide.
The emission spectrum and the results of identification of the most intense spectral lines of the atom and singly charged aluminum ion, as well as the spectral lines of the decay products of the chalcopyrite molecule in the plasma of overstressed nanosecond discharge between the aluminum and chalcopyrite electrode are shown in Fig. 6 and in Table 2.

At an air pressure of $13.3 \mathrm{kPa}$, the spectral lines of atoms and ions, the products of the electrode material and the decay of air molecules in the plasma, were observed against the background of broadband radiation of aluminum oxide nanostructures and continuous radiation, which may be due to thermal or recombination radiation of the plasma. As follows from [26], copper and indium atoms are less bound in the chalcopyrite molecule; therefore, the linear part of the plasma emission spectrum is mainly due to individual spectral lines of atoms and singly charged ions of copper and indium, as for gas-discharge plasma based on atmospheric pressure air [17]. The emission spectrum of air molecules consisted mainly of intense bands of the second positive system of the nitrogen molecule in the spectral range of $280-390 \mathrm{~nm}$, which is typical for the diffuse stage of overstressed nanosecond discharge [27], as well as individual spectral lines $\mathrm{N} 1$, N11 characteristic for the emission spectra of a spark discharge in air at atmospheric pressure [28]. 
Investigation of the Conditions of Synthesis of Metal and Chalcopyrite Films...

Proceeding from this, in the plasma emission spectra of vapor-gas mixtures based on aluminum, the products of the dissociation of the chalcopyrite molecule, air and the products of the dissociation of its molecules, the emission spectrum of the discharge plasma in the wavelength range of $200-240 \mathrm{~nm}$ consisted of a group of closely spaced spectral lines of the copper atom, a singly charged copper ion, as well as the lines of the

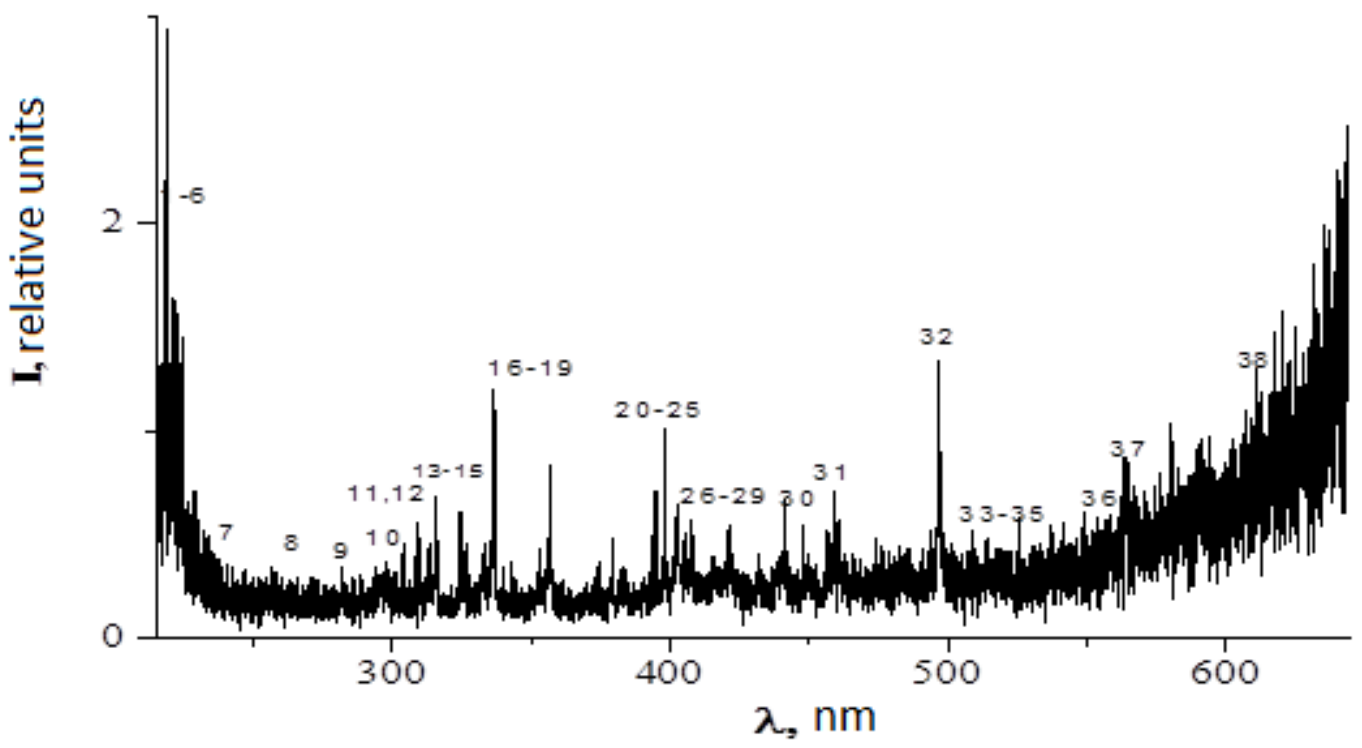

Fig. 6. Plasma emission spectrum of overstressed nanosecond discharge between aluminum and chalcopyrite electrodes at an air pressure of $13.3 \mathrm{kPa}$.

Table 2

Results of identification of the most intense spectral lines of the atom and singly charged aluminum ion and the lines of the decay products of the chalcopyrite molecule in an overstressed nanosecond discharge $(\mathrm{p}($ air $)=13.3 \mathrm{kPa})$.

\begin{tabular}{|c|c|c|c|c|c|c|c|}
\hline № & $\lambda, \mathrm{nm}$ & $\mathrm{I}_{\text {exp, }}$ a. u. & Objext & Elower., $\mathrm{eV}$ & $\mathrm{E}_{\text {upper., }} \mathrm{eV}$ & Lower Term & Upper Term \\
\hline 1 & 214.89 & 1.39 & $\mathrm{Cu} \mathrm{I}$ & 1.39 & 7.18 & $4 s^{22} \mathrm{D}$ & $5 \mathrm{f}^{2} \mathrm{~F}^{\circ}$ \\
\hline 2 & 218.17 & 1.98 & $\mathrm{Cu} \mathrm{I}$ & 0.00 & 5.68 & $4 s^{2} S$ & $4 p^{\prime 2} P^{0}$ \\
\hline 3 & 219.56 & 1.87 & $\mathrm{Cu}$ II & 8.78 & 14.43 & $4 p^{3} D^{o}$ & $4 d^{3} \mathrm{~F}$ \\
\hline 4 & 219.95 & 1.74 & $\mathrm{Cu} \mathrm{I}$ & 1.39 & 7.02 & $4 \mathrm{~s}^{2} \mathrm{D}$ & $4 p^{\prime \prime 2} D^{0}$ \\
\hline 5 & 221.45 & 1.64 & $\mathrm{Cu} \mathrm{I}$ & 1.39 & 6.98 & $4 s^{22} \mathrm{D}$ & $4 p^{\prime \prime 2} \mathrm{P}^{0}$ \\
\hline 6 & 225.80 & 1.27 & $\mathrm{Al} \mathrm{I}$ & 0.00 & 5.49 & $3 p^{2} \mathrm{P}^{0}$ & $7 \mathrm{~s}^{2} \mathrm{~S}$ \\
\hline 7 & 239.07 & 0.35 & $\mathrm{Al}$ II & 13.07 & 18.26 & $4 p^{3} \mathrm{P}^{0}$ & $10 d^{3} D$ \\
\hline 8 & 261.83 & 0.29 & $\mathrm{Cu} \mathrm{I}$ & 1.39 & 6.12 & $4 s^{2}{ }^{2} \mathrm{D}$ & $5 p^{2} \mathrm{P}^{0}$ \\
\hline 9 & 284.02 & 0.25 & $\mathrm{Al} \mathrm{I}$ & 4.02 & 8.39 & $3 d^{2} D$ & $3 d^{2} D^{\circ}$ \\
\hline 10 & 306.34 & 0.35 & $\mathrm{Cu} \mathrm{I}$ & 1.64 & 5.68 & $4 \mathrm{~s}^{2}{ }^{2} \mathrm{D}$ & $4 \mathrm{p}^{\prime 2} \mathrm{P}^{0}$ \\
\hline 11 & 308.21 & 0.47 & $\mathrm{Al} \mathrm{I}$ & 0.00 & 4.02 & $3 p^{2} \mathrm{P}^{0}$ & $3 d^{2} D$ \\
\hline 12 & 309.27 & 0.55 & $\mathrm{Al} \mathrm{I}$ & 0.01 & 4.02 & $3 \mathrm{p}^{2} \mathrm{P}^{\mathrm{o}}$ & $3 d^{2} D$ \\
\hline 13 & 324.75 & 0.61 & $\mathrm{Cu} \mathrm{I}$ & 0 & 3.82 & $4 s^{2} S$ & $4 p^{2} \mathrm{P}^{0}$ \\
\hline 14 & 327.39 & 0.44 & $\mathrm{Cu} \mathrm{I}$ & 0 & 3.39 & $4 \mathrm{~s}^{2} \mathrm{~S}$ & $4 p^{2} P^{0}$ \\
\hline 15 & 329.05 & 0.45 & $\mathrm{Cu} \mathrm{I}$ & 5.07 & 8.84 & $4 p^{\prime}{ }^{4} F^{0}$ & $4 \mathrm{~d}^{\prime}{ }^{4} \mathrm{~F}$ \\
\hline 16 & 337.13 & 1.05 & $\mathrm{~N}_{2}$ & \multicolumn{4}{|c|}{ Second positive system $\mathrm{C}^{3} \Pi_{\mathrm{u}}{ }^{+}-\mathrm{B}^{3} \Pi_{\mathrm{g}}{ }^{+}(0 ; 0)$} \\
\hline 17 & 344.60 & 0.31 & $\mathrm{~N}_{2}$ & \multicolumn{4}{|c|}{ Second positive system $\mathrm{C}^{3} \Pi_{\mathrm{u}}{ }^{+}-\mathrm{B}^{3} \Pi_{\mathrm{g}}{ }^{+}(4 ; 5)$} \\
\hline 18 & 357.69 & 0.82 & $\mathrm{~N}_{2}$ & \multicolumn{4}{|c|}{ Second positive system $\mathrm{C}^{3} \Pi_{\mathrm{u}}{ }^{+}-\mathrm{B}^{3} \Pi_{\mathrm{g}}^{+}(0 ; 1)$} \\
\hline 19 & 375.54 & 0.31 & $\mathrm{~N}_{2}$ & \multicolumn{4}{|c|}{ Second positive system $C^{3} \Pi_{u^{+}-B^{3} \Pi_{\mathrm{g}}{ }^{+}(1 ; 3)}$} \\
\hline 20 & 394.40 & 0.72 & $\mathrm{Al} \mathrm{I}$ & 0.00 & 3.14 & $3 p^{2} \mathrm{P}^{0}$ & $4 \mathrm{~s}^{2} \mathrm{~S}$ \\
\hline 21 & 396.15 & 1 & $\mathrm{Al} \mathrm{I}$ & 0.01 & 3.14 & $3 p^{2} P^{0}$ & $4 \mathrm{~s}^{2} \mathrm{~S}$ \\
\hline 22 & 402.26 & 0.61 & $\mathrm{Cu} \mathrm{I}$ & 3.79 & 6.87 & $4 p^{2} \mathrm{P}^{0}$ & $5 d^{2} D$ \\
\hline 23 & 405.67 & 0.48 & $\mathrm{Al} \mathrm{II}$ & 15.47 & 18.52 & $3 \mathrm{~s} 4 \mathrm{~d}^{1} \mathrm{D}$ & $3 \mathrm{~s} 15 \mathrm{p}{ }^{1} \mathrm{P}_{0}$ \\
\hline 24 & 409.48 & 0.39 & $\mathrm{~N}_{2}$ & \multicolumn{4}{|c|}{ Second positive system $\mathrm{C}^{3} \Pi_{\mathrm{u}}{ }^{+}-\mathrm{B}^{3} \Pi_{\mathrm{g}}{ }^{+}(4 ; 8)$} \\
\hline
\end{tabular}


Table 2

(continuation)

\begin{tabular}{|c|c|c|c|c|c|c|c|}
\hline 25 & 410.17 & 0.30 & In I & - & 3.02 & $5 s^{2} 5 p^{2} P^{o}$ & $5 s^{2} 6 s^{2} S_{1 / 2}$ \\
\hline 26 & 420.05 & 0.50 & $\mathrm{~N}_{2}$ & \multicolumn{4}{|c|}{ Second positive system $C^{3} \Pi_{u}{ }^{+}-B^{3} \Pi_{g}{ }^{+}(2 ; 6)$} \\
\hline 27 & 423.65 & 0.33 & $\mathrm{~N}_{2}$ & \multicolumn{4}{|c|}{ Second positive system $\mathrm{C}^{3} \Pi_{\mathrm{u}}{ }^{+}-\mathrm{B}^{3} \Pi_{\mathrm{g}}{ }^{+}(1 ; 2)$} \\
\hline 28 & 434.36 & 0.38 & $\mathrm{~N}_{2}$ & \multicolumn{4}{|c|}{ Second positive system $\mathrm{C}^{3} \Pi_{\mathrm{u}}{ }^{+}-\mathrm{B}^{3} \Pi_{\mathrm{g}}{ }^{+}(0 ; 4)$} \\
\hline 29 & 441.67 & 0.57 & $\mathrm{~N}_{2}$ & \multicolumn{4}{|c|}{ Second positive system $\mathrm{C}^{3} \Pi_{\mathrm{u}}{ }^{+}-\mathrm{B}^{3} \Pi_{\mathrm{g}}{ }^{+}(3 ; 8)$} \\
\hline 30 & 451.13 & 0.54 & In I & 0.27 & 3.02 & $5 s^{2} 5 p^{2} \mathrm{P}^{0}$ & $5 s^{2} 6 s^{2} S_{112}$ \\
\hline 31 & 459.97 & 0.71 & $\mathrm{~N}_{2}$ & \multicolumn{4}{|c|}{ Second positive system $\mathrm{C}^{3} \Pi_{\mathrm{u}}{ }^{+}-\mathrm{B}^{3} \Pi_{\mathrm{g}}^{+}(2 ; 4)$} \\
\hline 32 & 500.51 & 1.33 & N II & 25.50 & 27.97 & $3 \mathrm{~s}^{5} \mathrm{P}$ & $3 p^{5} P^{0}$ \\
\hline 33 & 510.55 & 0.42 & $\mathrm{Cu} \mathrm{I}$ & 1.39 & 3.82 & $4 \mathrm{~s}^{22} \mathrm{D}$ & $4 \mathrm{p}^{2} \mathrm{P}^{0}$ \\
\hline 34 & 515.83 & 0.47 & $\mathrm{Cu} \mathrm{I}$ & 5.69 & 8.09 & $4 \mathrm{p}^{\prime 2} \mathrm{P}^{\circ}$ & $5 s^{\prime 2} \mathrm{D}$ \\
\hline 35 & 521.82 & 0.40 & $\mathrm{Cu} \mathrm{I}$ & 3.82 & 6.19 & $4 \mathrm{p}^{2} \mathrm{P}^{\mathrm{o}}$ & $4 \mathrm{~d}^{2} \mathrm{D}$ \\
\hline 36 & 556.69 & 0.55 & Se II & & & & \\
\hline 37 & 566.66 & 0.82 & N II & 18.46 & 20.65 & $2 s^{2} 2 p 3 s^{3} P^{0}$ & $2 s^{2} 2 p 3 p^{3} D$ \\
\hline 38 & 618.86 & 1.18 & $\mathrm{Cu}$ II & 14.99 & 16.99 & $4 \mathrm{p}^{\prime \prime}{ }^{1} \mathrm{D}^{0}$ & $5 d^{3} F$ \\
\hline
\end{tabular}

atom and the singly charged ion of aluminum (spectral lines 1-7; Table 2). The spectral lines of copper were similar to those found in the radiation spectra of overstressed nanosecond discharge between copper or chalcopyrite electrodes in atmospheric pressure air at a distance between the copper electrodes $\mathrm{d}=1.2 \mathrm{~mm}$ [17].

A group of intense spectral lines and bands is located in the spectral range of $250-390 \mathrm{~nm}$ (lines and bands 8 20; Table 2). For this part of the spectrum, the most characteristic were the spectral lines of copper and aluminum atoms, as well as bright bands of the second positive system of the nitrogen molecule. The presence of intense bands of the nitrogen molecule of the $\mathrm{C}^{3} \Pi_{\mathrm{u}}{ }^{+}-$ $\mathrm{B}^{3} \Pi_{\mathrm{g}}{ }^{+}$system indicates that, in addition to the "runaway" electrons, the main part of the electron energy distribution function also contains electrons, whose energies are in the range of $9-18 \mathrm{eV}$, which are responsible for the emission of the molecule nitrogen in the spectral range of $290-410 \mathrm{~nm}$.

The emission of indium atoms in the visible region of the spectrum was represented by spectral lines 410.17 ; $451.13 \mathrm{~nm}$ In I. The characteristic spectral line of the nitrogen ion with a wavelength $\lambda=500.5 \mathrm{~nm} \mathrm{~N}$ II, which is observed in the emission spectra of nanosecond discharges in air, also appeared in the plasma radiation spectrum [28]. The characteristic spectral lines of the copper atom in the visible range of the spectrum 510.55 ; 515.83; 521.04; $556.69 \mathrm{~nm} \mathrm{Cu} \mathrm{I} \mathrm{had} \mathrm{low-intensity,} \mathrm{in}$ contrast to the case of overstressed nanosecond discharge plasma between copper electrodes in nitrogen or air, when there was an effective process of energy transfer from nitrogen molecules in metastable states to copper atoms $[29,30]$. In the red region of the spectrum, the $618.86 \mathrm{~nm}$ spectral line of $\mathrm{Cu}$ II was distinguished by its intensity.

In the yellow-red region in the spectrum of plasma radiation (Fig. 5), a continuum was recorded, the intensity of which increased with increasing wavelength in the range $550-665 \mathrm{~nm}$, against the background of which individual spectral lines of low intensity and molecular bands were observed, which can be attributed to radiation selenium molecules and products of their dissociation in the discharge.
The density of electrons in the plasma of overstressed discharges of nanosecond duration with the ectonic mechanism of electrode sputtering can reach $10^{16}-10^{17} \mathrm{~cm}^{-3}$ [31]. Therefore, the mechanism of formation of excited metal ions (copper, aluminum) in plasma can be determined by the processes of their excitation by electrons from the ground state of the corresponding ion. After this, electron-ion recombination processes begin to manifest themselves in the afterglow of the discharge. So, for zinc ions, the corresponding effective cross sections for the excitation of zinc ions by electrons in the ground energy state reach $-10^{-16} \mathrm{~cm}^{2}$ [32].

\section{Radiation transmission spectra of synthesized films}

In the wavelength range of $200-400 \mathrm{~nm}$, the absorption coefficient of thin films of ternary chalcopyrite $\mathrm{CuInSe}_{2}$ values and is within the range (4 -6) $\times 10^{5} \mathrm{~cm}^{-1}$ [33]. With an increase in the radiation wavelength to $1000 \mathrm{~nm}$, the absorption coefficient decreases to $10^{4} \mathrm{~cm}^{-1}$, and in the spectral range of 1000 $1200 \mathrm{~nm}$ it still decreases to $10 \mathrm{~cm}^{-1}$. That is, the absorption coefficient of light, which leads to the peculiarities of its use in photovoltaics, is significant, but strongly depends on the wavelength and is limited in the near infrared region of the spectrum. This implies the need to expand the forbidden zone of this semiconductor, and to increase the absorption coefficient of light in the near infrared region of the spectrum. This can be realized by transforming the $\mathrm{CuInSe}_{2}$ compound into thin films of quaternary chalcopyrite of the CuAlInSe 2 type.

Typical UV transmission spectra of thin films, presumably based on a quaternary compound of the $\mathrm{CuAlInSe}_{2}$ type, in the spectral range of $200-500 \mathrm{~nm}$ at various air pressures in the discharge chamber are shown in Fig. 7. The light transmission spectra of these films were obtained using UV radiation from a deuterium lamp. The methods and technique of this experiment is more fully presented in $[34,35]$. 


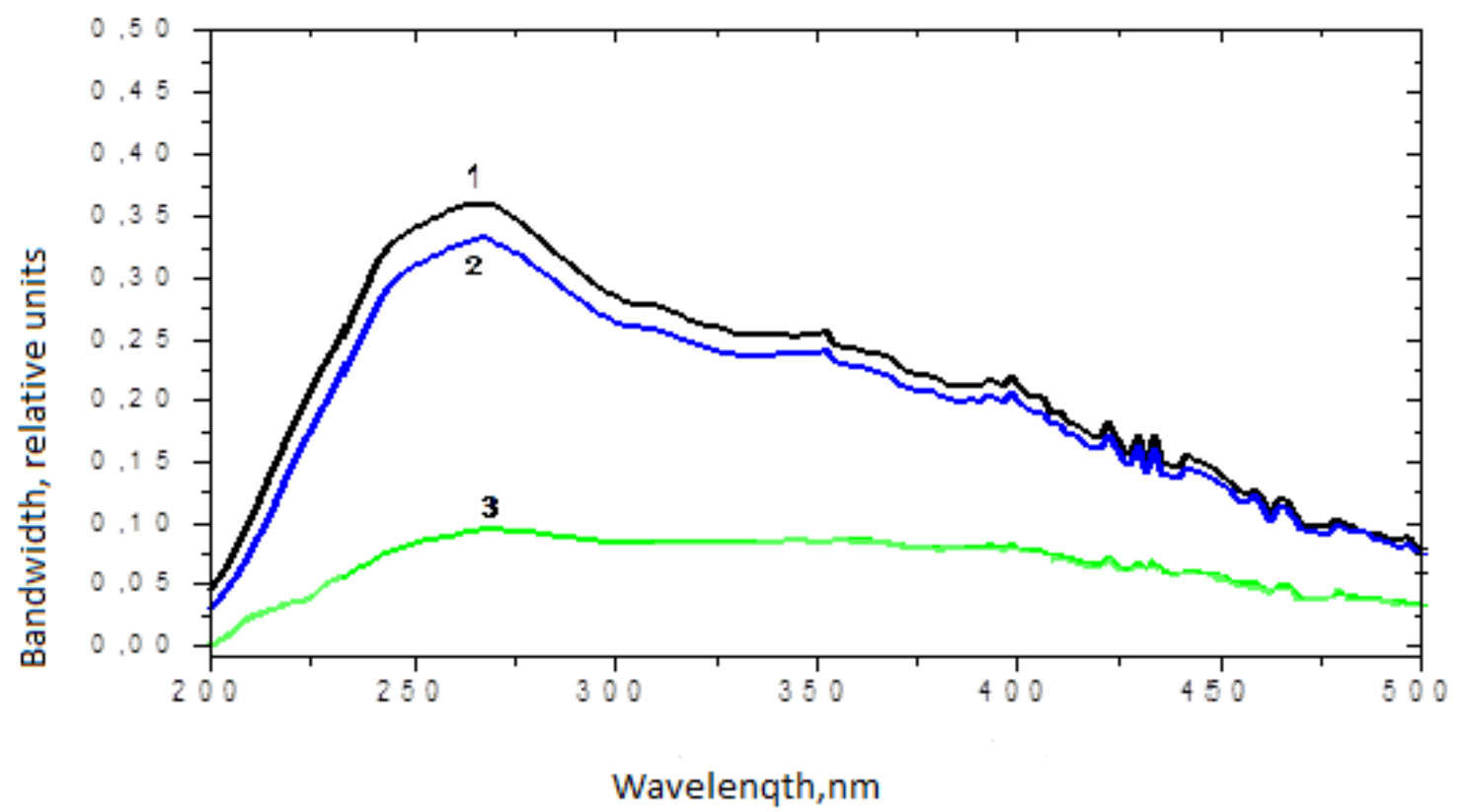

Fig. 7. The light transmission spectra of films, probably based on a mixture of ternary and quaternary chalcopyrite, which were deposited on quartz substrates, at different air pressures in the discharge chamber and when probed with radiation from a deuterium lamp: 0 - no sample; 1 - pure quartz glass; 2- electrodes: one of CuInSe $\mathrm{C}_{2}$, the second of aluminum at an air pressure of $13.3 \mathrm{kPa} ; 3$ - electrodes: one of $\mathrm{CuInSe}_{2}$, the second of aluminum at an air pressure of $101.3 \mathrm{kPa}$.

The transmission of thin chalcopyrite films, in comparison with the transmission of the substrate, decreased by up to four times, and for the film that was synthesized using a discharge in air, it was minimal at atmospheric pressure. The shapes of the transmission spectra for chalcopyrite films at air pressures of 13.3 and $101.3 \mathrm{kPa}$ were similar. The decrease in the transmission of a thin film that was synthesized at atmospheric air pressure as compared to the transmission of a film synthesized at an air pressure of $13.3 \mathrm{kPa}$ may be due to the thinner film thickness, which was synthesized at low air pressure, since the energy contribution to the plasma at atmospheric pressure air and, accordingly, the amount of sprayed material of the electrode material is greater.

\section{Conclusions}

Thus, it was found that at argon pressures of $6.7 \mathrm{kPa}$ and air pressure of $13.3 \mathrm{kPa}$ between copper electrodes, as well as an aluminum electrode and an electrode from chalcopyrite $\left(\mathrm{CuInSe}_{2}\right)$ with an interelectrode distance of 2; $1 \mathrm{~mm}$, an intense nanosecond discharge, uniform in space, was ignited with a pulsed electric power of up to 0.6 MW (in argon) and 3.0 MW (in air), and the energy contributions to the plasma in one pulse were 30 and $165 \mathrm{~mJ}$, respectively.

The study of the spectral characteristics of plasma based on vapor-gas mixtures "copper-argon" and "air-Al$\mathrm{CuInSe}_{2} "$ showed that the most intense were the spectral lines of the atom and singly charged copper ion in the range $200-225 \mathrm{~nm}$, the spectral lines of atoms and singly charged aluminum ions in the range wavelengths $225-310 \mathrm{~nm}$, as well as the lines of the atom of aluminum, indium and copper in the range of the spectrum 310 - $525 \mathrm{~nm}$. The $618.86 \mathrm{~nm} \mathrm{Cu11} \mathrm{line} \mathrm{stood}$ out from the ionic spectral lines in the spectrum. All spectral lines of metal atoms and ions, which were the constituents of the electrode material, were observed against the background of a wide band of nanostructures of aluminum oxide, thermal and recombination plasma radiation. Automatic irradiation of the substrate and film nuclei on the substrate with intense UV radiation of copper atoms and ions of the discharge plasma is promising for influencing the electrical characteristics of the synthesized films, in particular, reducing their resistance. The presence of the main spectral lines of aluminum, copper, and indium in the plasma emission spectra allows us to assume the possibility of deposition of a thin film of quaternary chalcopyrite - CuAlInSe outside the plasma media, as it was realized for ternary chalcopyrite.

The study of the transmission spectra of probing radiation in the wavelength range of $200-550 \mathrm{~nm}$ by films based on ternary chalcopyrite and aluminum vapor, which were synthesized by a pulsed gas-discharge method in air, showed that the lowest transmission is for films that were synthesized at atmospheric air pressure. 


Shuaibov A.K. - Ph.D., Professor of Quantum
Electronics;
Minya A.I. - Associate Professor of Quantum
Electronics;
Grytsak R.V. - researcher at the Department of Quantum
Electronics;
Malinina A.A. - PhD, senior employee of the
Department of Quantum Electronics;

Shevera I.V. - senior lecturer at the Department of Quantum Electronics;

Vatrala M.I. - graduate student of the Department of Quantum Electronics;

Gomoki Z.T. - employee of the Department of Quantum Electronics.

[1] G.G. Savenkov, S.A. Rashkovsky, V.A. Morozov, A.A. Lukin and others, ZhTF 87(9), 1327 (2017) (https://doi.org/10.21883/JTF.2017.09.44906.2112).

[2] A.K. Shuaibov, A.Y. Minya, A.A. Malinina, A.N. Malinin, V. V. Danilo, M.Yu. Sichka, I.V. Shevera, Amerikan Journal of Mechanical and Materials Engineering 2(1), 8 (2018) (https://doi.org/10.24966/BRB$\underline{0019 / 100005})$.

[3] A.Shuaibov, A. Minya, A. Malinina, A. Malinin, R. Golomd, I. Shevera, Advances in Natural Sciences: Nanoscience and Nanotechnology 9, 035018 (2018).

[4] O.K. Shuaibov, A.Y. Minya, M.P. Chuchman, A.O. Malinin, V.V. Danilo, Z.T. Homoki, Ukrainian Physical Journal 63(9), 790 (2018).

[5] O.K. Shuaibov, O.Y. Minya, Z.T. Gomoki, VV Danilo Windowless, spot, ultraviolet lamp. Utility model patent. U 2016 04596, 10.11.2016, Bull. № 21 .

[6] T.E. Itina, A. Voloshko, Appl. Phys. B. Laser and Optics (2013) (https://doi.org/10.1007/s00340-013-5490-6).

[7] G.A. Mesyats, Usp. Fizich. Nauk. 165(6), 601 (1995).

[8] J. Lopez-Garcia, M. Placidi, X. Fontane, V. Izguierdo-Roca, M. Espindola et all, Solar Energy Materials \& Solar Cells 132, 245 (2015).

[9] B. Farmanfarmas, M.R. Rashidian Vaziri, F. Khadzhiismailbaizhi, Quantum Electronics 44(11), 1029 (2014).

[10] A.K. Shuaibov, G.E. Laslov, and Ya.Ya. Kozak, Optics and Spectroscopy 116(4), 552 (2014).

[11] A.K. Shuaibov, G.E. Laslov, A.I. Minya, and Z.T. Gomoki, Technical Physics Letters 40(11), 963 (2014).

[12] A.Kh. Abduev, A.Sh. Asvarov, A.K. Akhmetov, R.M. Emirov, V.V. Belyaev, Technical Physics Letters 43(22), 40 (2017).

[13] V.G. Melnikov, Protection of metals 41(2), 168 (2005).

[14] Kh.V. Allakhverdieva, Izv. Vyssh. Uchebn. Zaved. Khim. Khim. Tekhnol [Russ. J. Chem \& Chem.Tech. 63(10), 71 (2020).

[15] L.F. Abaeva, V.I. Shumsky, E.N. Petritskaya, D.A. Rogatkin, P.N. Lyubchenko, Almanac of Clinical Medicine 22, 10 (2010).

[16] E.A. Farberova, A.Yu. Katysheva, S.A. Smirnov, E.A. Tingaeva, A.G. Starostin, Izvestiya vuzov. Chemistry and chemical technology 63(3), 46 (2020).

[17] O.K. Shuaibov, A.O. Malinina, O.M. Malinin, New gas - discharge methods for obtaining selective ultraviolet and visible radiation and synthesis of nanostructures of transition metal oxides. Monograph (Uzhhorod National University Publishing House "Hoverla", Uzhhorod, 2019).

[18] A.K. Shuaibov, A.I. Minya, A.A. Malinina, R.V. Gritsak, A.N. Malinin, Ukr. J. Phys. 65(5), 400 (2020).

[19] A. Shuaibov, A. Minya, A. Malinina, A. Malinin, Z. Gomoki, Highlights in BioScience 3, (2020). (Article ID 20211. (https://doi.org/10.36462/H.BioSci.20211).

[20] Runaway electrons preionized diffuse discharge. Ed. by V.F. Tarasenko (Nova Science Publishers Inc., New York, 2014).

[21] A.R. Striganov, N. Sventitsky, Tables of spectral lines of neutral and ionized atoms (Atomizdat, Moscow, 1966).

[22] NIST Atomic Spectra Database Lines Form (https:// physics.nist.gov/ PhysRefData/ASD/lines_form.html).

[23] R. Pierce, A. Gaydon, Identification of molecular spectra (Iz-vo IL, Moscow, 1949). (https://doi.org/10.15826/analitika.2016.20.1.005).

[24] V.S. Kortov, A.E. Ermakov, A.F. Zatsepin, M.A. White, S.V. Nikiforov et al., Solid State Physics 50(5), 916 (2008).

[25] I.V. Gassenkova, N.I. Mukhurov, Yasin Mokhsin Vakhioh, Reports of BSUIR 2(96), 114 (2016).

[26] I.E. Kacher, A.K. Shuaibov, M.Yu. Regan, A.I. Dashchenko, Thermal physics of high temperatures 40(6), 880 (2002).

[27] D.V. Beloplotov, M.I. Lomaev, D.A. Sorokin, V.F. Tarasenko, Journal of technical physics 88(6), 819 (2018). (https://doi.org/10.21883/JTF.2018.06.46032.2465).

[28] R.M. van der Horst, T. Verreycken, van E.M. Veldhuizen, and P.J. Bruggerman, J.Phys.D: Appl. Phys. 45, 345201 (2012).

[29] D.V. Beloplotov, V.I. Lomaev, D.A. Sorokin, V.F. Tarasenko, Journal of Physics : Conference Series 652, 012012 (2015) (https://doi.org/10.1088/1742-6596/652/1/012012). 
[30] M. Lomaev, D. Beloplotov, D. Sorokin, V. Tarasenko, The radiative properties of plasma of pulse-periodic discharge initiated wich runaway electrons. 32 $2^{\text {nd }}$ ICPIC. July 26-31 (Jasi, Romania, 2015). (https://doi.org/10.15407/ujpe62.07.0594).

[31] D. Levko, and Laxminarayan L.Raja, Physics of Plasmas 22, 123518 (2016) (https://doi.org/10.1063/1.4939022).

[32] A.N. Gomonai, Journal of Applied Spectroscopy 82(1), 17 (2015).

[33] G.F. Novikov, M.V. Gapanovich, Successes in physical sciences 187(2), 173 (2017).

[34] V.M. Holovey, K.P. Popovych, M.V. Prymak, M.M. Birov, V.M. Krasilinets, V.I. Sidey, Physica B 450,34 (2014).

[35] V.M. Krasylynets, O. K. Shuaibov, I.V. Shevera, Z.T. Gomoki, M.M. Chavarga, A.M. Solomon, V. I. Mikla, Uzhhorod University Scientific Herald Series Physics. 46, 84 (2019) (https://doi.org/10.24144/2415$\underline{8038.2019 .46 .84-91})$.

О.К. Шуаібов, О.Й. Миня, Р.В. Грицак, А.О. Малініна, І.В. Шевера, М.I. Ватрала, 3.T. Гомокі

\section{Дослідження умов синтезу металевих і халькопіритових плівок 3 продуктів деструкції електродів перенапруженого наносекундного розряду в аргоні і повітрі}

ДВНЗ «Ужгородський начіональний університет», м.Ужгород, Україна, alexsander.shuаibov@uzhnи.еdu.иа

Приведено характеристики перенапруженого біполярного розряду тривалістю 100 - 150 нс в аргоні і повітрі, який запалювався між електродами з міді в аргоні, а також між електродом 3 алюмінію i електродом а халькопіриту $\left(\mathrm{CuInSe}_{2}\right)$ в повітрі. В процесі мікровибухів неоднорідностей на робочих поверхнях електродів в сильному електричному полі в міжелектродний проміжок вносяться пари міді, алюмінію і пари потрійного халькопіриту. Це створює передумови для синтезу тонких плівок міді і синтезу плівок на основі четверного халькопіриту - CuAlInSe 2 , які можуть осаджувались на кварцовій пластині, встановленій поблизу від центру розрядного проміжку.

Методом емісійної спектроскопії з високим часовим розділенням досліджено оптичні характеристики плазми, а також імпульси напруги на розрядному проміжку величиною $\mathrm{d}=1$ 2 мм, імпульси струму і імпульсний енергетичних внесок в розряд. Ретельно досліджені спектри випромінювання плазми, що дозволило встановити основні продукти розпаду молекули халькопіриту і енергетичні стани атомів та однозарядних іонів алюмінію, міді і індію, які утворюються в розряді.

На основі продуктів деструкції електродів з алюмінію і потрійного халькопіриту осаджено за межами плазми тонкі плівки, які можуть мати склад четверного халькопіриту, досліджено спектри пропускання тонких плівок, осаджених при різних тисках повітря в розрядній камері.

Ключові слова: розряд, халькопіритні плівки, аргон, електроди. 